\title{
MODAL SOSIAL KOMUNITAS YOGYAKARTA MENGAJAR DALAM PENYELENGGARAAN PENDIDIKAN NONFORMAL DI KAMPUNG GEMBLAKAN BAWAH KOTA YOGYAKARTA
}

\author{
Reza Falufi ${ }^{1}$ dan Francisca Winarni ${ }^{2}$ \\ Jurusan Ilmu Administrasi Negara, Fakultas Ilmu Sosial, Universitas Negeri Yogyakarta \\ 1falufireza14@gmail.com \\ 2rancisca_winarni@uny.ac.id
}

\begin{abstract}
The purpose of this research is to know and describe Social Capital of Yogyakarta Mengajar Community in the Implementation of Nonformal Education in Kampung Gemblakan Bawah Kota Yogyakarta. This research was a descriptive with qualitative approach research. The findings of the research showed that social capital of Yogyakarta Mengajar community in the implementation of nonformal education in Kampung Gemblakan Bawah Kota Yogyakarta is able to mobilize internal resources and build network outside the community. This can be seen through six indicators, namely: (1) the characteristic of social community that structured and systematic, (2) network and support from society and external community (3) collective action through reguler meetings with each other between fellow volunteers and community boards, (4) the trust established a strong, (6) the harmoniousness that exists because the volunteers consistently obey the values and norms prevailing in society.
\end{abstract}

Keywords: Social Capital, Nonformal Education, and Yogyakarta Mengajar Community

\begin{abstract}
Abstrak
Penelitian ini bertujuan untuk mengetahui dan mendeksripsikan Modal Sosial Komunitas Yogyakarta Mengajar dalam penyelenggaraan pendidikan nonformal di Kampung Gemblakan Bawah Kota Yogyakarta. Desain penelitian yang digunakan adalah metode deskriptif dengan pendekatan kualitatif. Hasil penelitian menunjukkan bahwa modal sosial Komunitas Yogyakarta Mengajar Modal Sosial komunitas Yogyakarta Mengajar dalam penyelenggaraan pendidikan nonformal di kampung Gemblakan Bawah Kota Yogyakarta mampu memobilisasi sumber daya internal dan membangun jaringan diluar komunitas. Hal ini dapat dilihat dari enam indikator, yaitu : (1) karakteristik komunitas sosial yang terstruktur dan sistematis, (2) jaringan dan dukungan dari masyarakat dan eksternal komunitas, (3) tindakan kolektif melalui pertemuan rutin satu sama lain antara sesama relawan dan pengurus bersama masyarakat,, (4) kepercayaan yang terjalin kuat, (5) solidaritas internal komunitas tinggi, (6) keharmonisan yang terjalin karena relawan konsisten menaati nilai-nilai serta norma yang berlaku di masyarakat.
\end{abstract}

Kata kunci: Modal Sosial, Pendidikan Nonformal, dan Komunitas Yogyakarta Mengajar

Diterima 15 Maret 2018; Diterima dengan revisi 5 April 2018; Dipublikasikan 1 Mei 2018

2406-9515 (p) / 2528-441X (e)

(C) 2018 Reza Falufi dan Francisca Winarni. Dipublikasikan oleh JIAN FIS UNY 


\section{PENDAHULUAN}

Pendidikan merupakan instrumen yang amat penting bagi seluruh negara untuk meningkatkan daya saingnya dalam mekanisme politik, ekonomi, hukum dan pertahanan pada tata kehidupan masyarakat dunia global. Pendidikan yang berkualitas dapat menciptakan sumber daya manusia unggul dan produktif. Manusia adalah kekuatan utama dalam seluruh bidang pembangunan bangsa, dan oleh karena itu pembangunan pendidikan harus terpadu dan berjalan secara seirama, selaras, dan serasi dengan pembangunan pada bidangbidang lainnya.

Undang-undang No. 20 tahun 2003 tentang Sistem Pendidikan Nasional menegaskan bahwa pendidikan dilakukan melalui tiga jalur, yaitu : pendidikan formal, pendidikan nonformal, dan pendidikan informal.

Pendidikan formal adalah kegiatan yang sistematis, bertingkat/berjenjang, dimulai dari sekolah dasar sampai dengan perguruan tinggi dan yang setaraf dengannya. Pendidikan nonformal adalah pendidikan yang dilakukan secara teratur,dengan sadar dilakukan, tetapi tidak terlalu ketat mengikuti peraturanperaturan yang tetap, seperti pada pendidikan formal di sekolah. Pendidikan informal merupakan proses pelaksanaan pendidikan yang dilakukan oleh keluarga sepanjang hidup.

Pelaksanaan pendidikan formal, pendidikan nonformal dan pendidikan informal merupakan proses satu kesatuan yang mendukung satu sama lain. Pendidikan formal membutuhkan sebuah dukungan dari pelaksanaan pendidikan lainnya, dalam hal keahlian (soft skill) yang diperlukan untuk lebih diperdalam diluar pelaksanaan sekolah formal. Pendidikan nonformal dapat dijadikan alternatif dalam memberikan pengembangan keahlian seorang individu.

Keberhasilan siswa dalam mengikuti kegiatan pembelajaran di sekolah formal di Daerah Istimewa Yogyakarta juga masih memiliki beberapa kendala. Hal ini dapat terlihat dengan jumlah siswa mengulang atau tidak naik kelas khususnya pada tingkat sekolah dasar yang memiliki angka tertinggi.

Tabel 1. Jumlah Siswa Mengulang DIY

\begin{tabular}{|l|l|l|l|}
\hline \multirow{2}{*}{$\begin{array}{l}\text { Tingkat } \\
\text { Pendidikan }\end{array}$} & \multicolumn{3}{|l|}{ Jumlah Siswa Mengulang } \\
& Provinsi DIY & \multicolumn{2}{|l|}{} \\
\cline { 2 - 4 } & 2014 & 2015 & 2016 \\
\hline SD/MI & $\mathbf{3 . 7 1 7}$ & $\mathbf{3 . 7 6 4}$ & $\mathbf{3 . 8 8 0}$ \\
\hline SMP/MTS & $\mathbf{2 5 8}$ & $\mathbf{1 9 5}$ & $\mathbf{2 3 2}$ \\
\hline $\begin{array}{l}\text { SMA/MA/ } \\
\text { SMK }\end{array}$ & $\mathbf{7 9 1}$ & $\mathbf{1 9 1}$ & $\mathbf{2 1 5}$ \\
\hline
\end{tabular}

Sumber: Ikhtisar Data Pendidikan dan Kebudayaan Kemendikbud (2016) 
Dapat dilihat pada Tabel 1 dalam kurun tahun 2014-2016 jumlah siswa mengulang pada tingkat sekolah dasar selalu mengalami peningkatan. Persentase siswa tidak naik kelas yang cukup tinggi berada pada kelas rendah, kelas I sampai dengan III. Pada kelas rendah tentunya anak perlu di dampingi secara insentif dalam pembelajaran. Perlunya tambahan pelajaran di luar pendidikan formal yaitu pendidikan nonformal.

Pendidikan nonformal dapat diselenggarakan oleh pemerintah, swasta atau inisiatif dari masyarakat. Pemerintah Provinsi Daerah Istimewa Yogyakarta mengatur pelaksanaan pendidikan nonformal dalam Peraturan Daerah Provinsi DIY Nomor 5 Tahun 2011 Pasal 29 tentang Penyelenggaraan Pendidikan Nonformal yang menyebutkan penyelenggaraan pendidikan nonformal adalah jalur pendidikan di luar pendidikan formal yang dapat dilaksanakan secara terstruktur dan berjenjang, dengan melaksanakan pembelajaran berdasarkan pada kurikulum pendidikan berbasis budaya, sehingga mampu mentransfernilai nilai luhur budaya yang berkembang dalam proses penyelenggaraan pendidikan.

Penyelenggaraan pendidikan nonformal di Kampung Gemblakan
Bawah oleh pemerintah dengan dibentuknya PKBM (Pusat Kegiatan Belajar Masyarakat) dalam pelaksanaannya terjadi beberapa kendala yang mengakibatkan PKBM dinonaktifkan. Pusat kegiatan belajar masyarakat (PKBM) menjadi tempat pelaksanaan pendidikan nonformal untuk masyarakat memperoleh keahlian. Sasarannya tidak hanya untuk usia dewasa, tetapi anak-anak yang sudah menduduki bangku sekolah dasar dapat sejak dini dilatih mengembangkan kemampuan yang dimilikinya. PKBM di Kampung Gemblakan Bawah, Kota Yogyakarta pada implementasinya sudah tidak aktif karena kekurangan tenaga pendidik serta metode pembelajaran yang kurang variatif.

Selain pemerintah, masyarakat juga mampu mendapatkan pendidikan nonformal yang diselenggarakan oleh pihak swasta. Kualitas yang ditawarkan oleh lembaga tersebut sama dengan jumlah harga yang harus dikeluarkan saat mengakses pelaksanaan pendidikan nonformal oleh pihak swasta sehingga masyarakat yang memiliki tingkat ekonomi kebawah tidak mampu untuk mengikuti anaknya dalam pelaksanaan pendidikan nonformal oleh swasta.

Keberadaan komunitas pendidikan di DIY selalu mengalami peningkatan 
setiap tahunnya. Hal ini tidak terlepas karena kondisi sosial masyarakat DIY yang masih memiliki sebuah modal sosial. Modal sosial merupakan sumberdaya yang telah dimiliki oleh setiap individu dengan indvidu lainnya karena hubungan yang telah terjalin lama. Modal sosial di era modernisasi mengalami beberapa tantangan karena terancam melemah mengakibatkan seseorang menjadi lebih individualistis. Modal Sosial mulai melemah dengan masuknya nilai-nilai asing yang tidak relevan dengan kearifan lokal karena perkembangan teknologi.

Masyarakat DIY memiliki modal sosial yang telah terjalin di dalam kehidupan bermasyarakat. Sikap seperti gotongroyong, toleransi, serta ramah terhadap pendatang merupakan perilaku yang menjadi modal sosial di dalam interaksi sosial antar masyarakat. Modal sosial tersebut dapat berperan dalam menjawab dinamika sosial yang terjadi pada lingkungan sekitar tempat tinggal.

Setiap komunitas sosial masyarakat yang terbentuk pasti memiliki berbagai alasan tertentu, termasuk Komunitas Yogyakarta Mengajar. Berawal dari lima mahasiswa Daerah Istimewa Yogyakarta yang berasal dari universitas berbeda yaitu Bonia Marlin Matita (UGM), Lyna Nasilatul Khamidah (UNY), Ratri Sekar
(UII), Ilham Dwi Ardiyansah (UPN Veteran Yogyakarta) dan Shoffan Anbiya Khalifatudin (Universitas Ahmad Dahlan) merupakan individu yang aktif dalam Forum Anak Nasional DIY semenjak masa Sekolah Menengah Atas membentuk sebuah gerakan sosial bernama Gangsal Angkringan yang kini lebih dikenal dengan Komunitas Yogyakarta Mengajar.

Komunitas sosial memiliki sumber dan potensi modal sosial yang dapat diakses dan dimanfaatkan oleh anggotanya (Alfitri, 2011 : 73) . Modal sosial dilahirkan dari bawah (bottom-up), tidak hierarkis dan berdasar pada interaksi yang saling menguntungkan. Komunitas relawan pendidikan merupakan suatu organisasi sosial, hal ini dikarenakan dalam suatu komunitas relawan pendidikan terdiri lebih dari satu individu yang bekerja sama dalam banyak hal dan memiliki struktur kepengurusan.

Modal sosial dalam penelitian ini menjadi hal yang memberi pengaruh besar terhadap penyelenggaraan pendidikan nonformal komunitas yogyakarta mengajar di Kampung Gemblakan Bawah, Kota Yogyakarta. Tanpa adanya modal sosial yang dimiliki masyarakat Kampung Gemblakan Bawah dan Komunitas Yogyakarta Mengajar, 
maka pelaksanaan kegiatan pendidikan nonformal akan berjalan tidak konsisten serta masyarakat tidak akan memberikan respon positif terhadap penyelenggaraan setiap agenda Komunitas Yogyakarta Mengajar.

Tujuan pelaksanaan penelitian ini adalah untuk mengetahui dan memahami secara jelas modal sosial Komunitas Yogyakarta Mengajar dalam penyelenggaraan pendidikan nonformal di Kampung Gemblakan Bawah, Kota Yogyakarta.

Definisi modal sosial menurut Bordieu (dalam Field, 2010:23), modal sosial adalah jumlah sumber daya, aktual atau maya, yang berkumpul pada seorang individu atau kelompok karena memiliki jaringan tahan lama berupa timbal balik perkenalan dan pengakuan yang sedikit banyak terinstitusionalisasikan.

Senada dengan Bourdieu, Coleman (dalam Field, 2010:37) menyebutkan bahwa modal sosial merupakan sumber yang bermanfaat yang tersedia bagi aktor melalui hubungan sosialnya. Hal ini mencakup berbagai entitas yang secara keseluruhan terdiri dari beberapa aspek struktur sosial dan itu semua memfasilitasi tindakan tertentu para aktor yang bekerja sama dalam struktur tersebut.
Modal Sosial masyarakat DIY dapat dilihat dari keseharian masyarakat yang masih memiliki nilai-nilai kearifan lokal dalam proses berkomunikasi satu sama lain. Sikap gotongroyong diutamakan untuk mempermudah beban pekerjaan dalam lingkup wilayah sekitar tempat tinggalnya. Rasa kepercayaan terhadap orang-orang baru yang ditemui selama memiliki niat baik dalam mengubah dinamika sosial yang terjadi di masyarakat.

Keterbukaan masyarakat Daerah Istimewa Yogyakarta terhadap gerakangerakan sosial komunitas masyarakat memberikan ruang untuk pemuda yang mayoritas berstatus mahasiswa mendirikan berbagai komunitas sosial kemasyarakatan seperti Pendar Foundation, Gunung Kidul Menginspirasi, Sanggar Anak Kali Code, 1000 Guru Jogja, Yogyakarta Mengajar.

Berbagai komunitas tersebut masih bertahan dan berjalan tidak terlepas dari nilai masyarakat Daerah Istimewa Yogyakarta selalu berinteraksi dengan ramah kepada indvidu-individu yang memiliki niat baik untuk gotong royong dalam kehidupan sosial kemasyarakatan.

Komunitas $\begin{aligned} & \text { Yogyakarta } \\ & \text { Mergerak pada bidang }\end{aligned}$
nondidikan
nonformal.


Menurut (Soelaman Joesoef, 2004:50) pendidikan nonformal adalah setiap kesempatan dimana terdapat komunikasi yang terarah di luar sekolah dan seseorang memperoleh informasi, pengetahuan, latihan maupun bimbingan sesuai dengan tingkat usia dan kebutuhan hidup, dengan tujuan mengembangkan tingkat keterampilan, sikap dan nilai-nilai yang memungkinkan baginya menjadi peserta-peserta yang efesien dan efektif lingkungan keluarga, pekerjaan bahkan lingkungan masyarakat dan negaranya. Komunitas Yogyakarta Mengajar termasuk dalam kelompok sosial.

Kelompok sosial adalah himpunan atau kesatuan manusia yang hidup bersama, karena adanya hubungan diantara mereka. Hubungan tersebut antara lain menyangkut hubungan timbal balik yang saling mempengaruhi dan juga suatu kesadaran untuk saling menolong. (Soerjono Soekanto, 2006:104). Merujuk pada Ridell (dalam Supriono, 2012 ), ada tiga parameter modal sosial, yaitu kepercayaan (trust), norma-norma (norms) dan jaringan-jaringan (networks).

Inti telaah dari modal sosial adalah mengenai soal hubungan. Modal sosial dapat dijelaskan sebagai produk relasi manusia satu sama lain, khususnya relasi yang intim dan konsisten. Relasi tersebut ditandai dengan adanya kerjasama dengan pola interelasi timbal balik dan saling menguntungkan, yang dibangun diatas kepercayaan berdasarkan norma dan nilai sosial.Dalam Penelitian ini peneliti menggunakan teori modal sosial menurut Badaruddin (2005:81-92) yang terdiri dari:

1. Karakteristik Komunitas Sosial

2. Jaringan dan Dukungan

3. Tindakan Kolektif

4. Kepercayaan

5. Solidaritas

6. Keharmonisan

Teori modal sosial menurut Badaruddin (2015:81-92) dipilih karena keenam indikator relevan dengan kondisi nyata pada modal sosial Komunitas Yogyakarta Mengajar dalam penyelenggaraan pendidikan nonformal di Kampung Gemblakan Bawah. Penelitian ini penting dilakukan karena diharapkan hasil dari penelitian ini dapat memberikan gambaran, masukan, dan rekomendasi untuk memperkuat modal sosial di era modernisasi serta pengoptimalan peran komunitas sosial oleh pemerintah.

\section{METODE}

Desain penelitian yang digunakan dalam penelitian ini adalah penelitian metode kualitatif. Metode kualitatif ini merupakan suatu metode untuk 
mengesplorasi dan memahami makna yang muncul dari suatu fenomena ataupun yang berasal dari suatu permasalahan sosial. Penelitian ini dilaksanakan pada bulan Januari hingga bulan April 2018. Subjek penelitian ini meliputi: 1) Ketua Komunitas Yogyakarta Mengajar, 2) Pengurus dan Relawan Komunitas Yogyakata Mengajar, 3) Masyarakat Kampung Gemblakan Bawah. Teknik analisis data dalam penelitian ini menggunakan teknik analisis interaktif yang dikemukakan oleh Moleong yang meliputi: 1) Reduksi data, 2) Penyajian data, dan 3) Penarikan kesimpulan.

\section{HASIL DAN PEMBAHASAN}

Yogyakarta Mengajar merupakan komunitas sosial kemasyarakatan. Bertahannya komunitas sosial selalu ada peran sebuah modal sosial. Modal sosial merupakan aspek penting dalam kehidupan sosial yang diharapkan mampu mengubah dinaimka sosial dalam berbagai aspek kegiatan terutama aksi sosial seperti komunitas Yogyakarta Mengajar.

Modal sosial dalam sebuah komunitas masyarakat seperti yang dikatakan Badaruddin (2005:81-92) adalah semua sumber daya yang tertanam karena adanya hubungan sosial.
Yogyakarta Mengajar dalam penyelenggaraan pendidikan nonformal di kampung Gemblakan Bawah telah dilaksanakan selama empat tahun. Modal sosial dalam penjelasan (Field, 2000:1) orang membangun hubungan melalui serangkaian jaringan dan mereka cenderung memiliki kesamaan nilai. Hubungan sosial terjalin antara relawan pengajar kampung Gemblakan Bawah dengan masyarakat karena kesamaan kebutuhan dalam pihak penyelenggara dan penerima pendidikan nonformal.

Proses memahami dan menilai mengenai modal sosial Komunitas Yogyakarta Mengajar dalam penyelenggaraan pendidikan nonformal di Kampung Gemblakan Bawah Kota Yogyakarta dianalis dengan menggunakan enam indikator dari Badaruddin (2005:81-92). Keenam indikator tersebut meliputi karakteristik komunitas sosial, jaringan dan dukungan, tindakan kolektif, kepercayaan, solidaritas, dan keharmonisan. Menurut Badaruddin (2005:81-92) komunitas kemasyarakatan memiliki karakter tersendiri. Komunitas tersebut dapat berkelanjutan terus menerus atau sebuah gerakan yang populis. Komunitas yang mampu untuk menciptakan iklim yang berkelanjutan memiliki pembagian kerja 
yang jelas serta tujuan yang ingin tercapai.

Selain itu, Badaruddin (2005:8192) menjelaskan bahwa alasan sebuah komunitas berdiri memiliki nilai historis untuk keberlangsungan kegiatan komunitas sosial. Komunitas Yogyakarta Mengajar terbentuk karena para pendiri memiliki kepedulian yang sama dalam pemerhati anak. Kepedulian tersebut menjadi landasan kuat untuk memulai sebuah aksi sosial. Kepedulian tersebut menjadikan keberlanjutan komunitas yang tetap ada selama empat tahun. Artinya sejalan dengan yang dikatakan Badaruddin (2005: 81-92) , individuindividu yang berada didalam internal komunitas Yogyakarta Mengajar mengedepankan keberlanjutan.

Hal ini dapat dilihat dari segi teknis menentukan nama calon ketua komunitas dilakukan melalui kaderirasi saat menjadi relawan pengajar. Para calon ketua komunitas akan dipilih secaara langsung oleh seluruh pengurus dan relawan komunitas. Mekanisme ini untuk melibatkan keseluruhan elemen komunitas karena nanti ketua terpilih akan memimpin komunitas yogyakarta mengajar selama satu tahun kepengurusan.

Mempersiapkan ketua sebagai pemimpin komunitas Yogyakarta
Mengajar menjadi sesuatu yang penting untuk perkembangan komunitas. Gaya kepemimpinan akan mempengaruhi pihak-pihak yang berada dibawahnya sehingga mendapatkan nama terbaik untuk menjadi ketua adalah hal mutlak. Kaderisasi melalui pengamatan saat seorang relawan berfungsi sejauh mana seseorang mampubertanggung jawab dalam menjalankan tugasnya.

Ketua komunitas Yogyakarta Mengajar tidak dapat bekerja sendiri. Individu-individu yang tergabung didalam struktur kepengurusan komunitas Yogyakarta Mengajar memiliki tugas pokok dan fungsinya masing-masing. Komunitas Yogyakarta Mengajar melakukan pembagian kerja dengan berbagai divisi yang dimiliki oleh komunitas Yogyakarta Mengajar.

Divisi tersebut terbagi menjadi publikasi dokumentasi, PSDM dan kreatif, humas, fundraising. Terbaginya berbagai divisi mengakibakan arahan kerja menjadi terarah dan terstruktur. Tidak ada tumpang tindih program kerja sehingga kegiatan komunitas mampu berjalan secara efektif dan efisien.

1. Jaringan dan Dukungan

Menurut Badaruddin (2005:81-

92) dukungan yang dimiliki oleh komunitas sosial karena adanya 
kebutuhan untuk mengubah dinamika sosial. Masyarakat secara sadar merasakan hadirnya komunitas tersebut dapat memperbaiki kehidupan sosial yang berada pada lingkup masyarakat.

Kehadiran Komunitas Yogyakarta Mengajar sejalan dengan apa yang dibutuhkan oleh masyarakat kampung Gemblakan Bawah. Dukungan yang diberikan masyarakat dilakukan secara maksimal karena memang yang akan menikmati hasilnya adalah masyarakat kampung Gemblakan Bawah itu sendiri.

Dukungan tersebut berupa penyediaan tempat dan dana untuk keberlangsungan kegiatan komunitas. Masyarakat kampung Gemblakan Bawah memiliki harapan yang tinggi dengan hadirnya para relawan pengajar komunitas Yogyakarta Mengajar. Terlebih masyarakat yang mengikutkan anaknya dalam pelaksanaan pendidikan nonformal komunitas Yogyakarta Mengajar tergolong kurang mampu secara ekonomi.

Dalam jaringan, Badaruddin (2005:81-92) menjelaskan komunitas sosial harus memiliki eksistensi serta kelebihan dibanding komunitas lainnya untuk mampu mengajak pihak-pihak eksternal komunitas ikut terlibat pada kegiatan komunitas. Komunitas Yogyakarta Mengajar sudah diuntungkan dengan latar belakang dari keberadaan relawan. Relawan komunitas Yogyakarta Mengajar kampung Gemblakan Bawah adalah mahasiswa yang berasal dari universitas berbeda. Relawan akan mendapatkan keuntungan sebuah jejaring perkenalan baru diluar lingkup kampus yang berguna untuk menambah kapasitas diri sebagai mahasiswa.

\section{Tindakan Kolektif}

Menurut Badaruddin (2005:8192) tindakan secara kolektif pada komunitas sosial adalah pengambilan keputusan yang selalu melibatkan pihak internal komunitas serta masyarakat yang menjadi sasaran kegiatan komunitas.

Relawan pengajar kampung Gemblakan Bawah memiliki porsi yang sama dalam pengambilan keputusan teknis desain bmbingan belajar nonformal di kampung Gemblakan Bawah. Metode pembelajaran yang akan digunakan saat hari pelaksanaan ditentukan dalam pertemuan rutin setiap minggunya relawan komunitas Yogyakarta Mengajar kampung Gemblakan Bawah.

Pengambilan keputusan komunitas Yogyakarta Mengajar secara umum selalu melibatkan seluruh relawan komunitas Yogyakarta Mengajar. Relawan memiliki hak penuh untuk 
bersuara dalam memberikan kritik dan saran perihal program-program komunitas Yogyakarta Mengajar.Kegiatan tersebut dilakukan melalui forum family gathering komunitas Yogyakarta Mengajar. Forum yang merupakan sharing kegiatan wilayah, evaluasi serta kegiatan-kegiatan komunitas Yogyakarta Mengajar yang melibatkan relawan keseluruhan. Yogyakarta Mengajar merupakan komunitas sosial, wujud kebersamaan dalam setiap keputusan selalu diutamakan.

\section{Kepercayaan}

Menurut Badaruddin (2005:8192) kepercayaan merupakan proses keyakinan dalam proses tindakan kerja yang dilakukan sesuai dengan yang diharapkan. Kepercayaan pada komunitas sosial timbul karena adanya hasil konkrit yang telah dilakukan oleh komunitas.

Kepercayaan yang terjalin antar relawan pengajar terlihat dalam pembagian kerja saat pelaksanaan bimbingan belajar nonfomal di kampung Gemblakan Bawah. Relawan saling percaya dengan kemampuan kinerja satu sama lain dengan tidak melihat latarbelakang pendidikan dari relawan, semua mencoba hal-hal baru untuk mendapatkan pengalaman yang sama.
Hasil yang didapat para peserta didik seperti meraih prestasi perlombaan serta perubahan perilaku anak yang menjadi lebih santun dalam bersikap memberikan kepercayaan masyarakat terhadap relawan komunitas Yogyakarta Mengajar. Rasa percaya masyarakat terhadap kegiatan komuntias Yogyakara Mengajar dapat terlihat dari dukungan yang diberikan oleh masyarakat.

Masyarakat juga mengakui kapasitas para relawan sebagai seseorang yang mampu berkontribusi di masyarakat. Kepercayaan terhadap kemampuan para relawan diperlihatkan ketika mengajak relawan untuk bergabung dalam kepanitiaan acara kampung yang tidak memiliki hubungan dengan pelaksanaan kegiatan komunitas. Bila masyarakat tidak memiliki rasa percaya kepada relawan, tidak mungkin mengajak terlibat dalam kegiatan kampung Gemblakan Bawah.

\section{Solidaritas}

Setiap individu yang mernjadi relawan dapat dikatakan memiliki rasa peduli yang tinggi sesame manusia. Tidak mungkin seorang yang individualis tergabung dalam kegiatan kerelawanan khususnya pengabdian masyarakat yang tidak ada bayaran secara materi. 
Menurut Badaruddin (2005:8192) solidaritas dalam komunitas sosial adalah sejauh mana seseorang berkomitmen mengembangkan komunitas sosial. Rasa solid yang dimiliki oleh relawan pengajar kampung Gemblakan Bawah komunitas Yogyakarta Mengajar ditunjukan dengan memberikan iuran secara rutin untuk menunjang pelaksanaan bimbingan belajar untuk anak kampung Gemblakan Bawah. Para relawan yang tidak dibayar tetapi justu mengeluarkan bantuan secara materi karena memiliki kepedulian yang tinggi perihal kegiatan komunitas Yogyakarta Mengajar.

Tindakan yang proaktif merupakan suatu keinginan yang kau dari anggota untuk tidak saja berpartisipasi tetapi senantiasa mencari jalan bagi keterlibatan dalam kegiatan masyarakat (Hasbullah, 2006: 63). Para relawan yang sudah tidak aktif tersebut dalam mendukung kegiatan komunitas Yogyakarta Mengajar dengan memberikan bantuan dana insentif untuk menunjang kegiatan komunitas Yogyakarta Mengajar. Relawan tetap berpegang teguh dengan tanggung jawab yang dimiliki untuk ikut terlibat dalam komunitas Yogyakarta Mengajar, sehingga komunitas Yogyakarta Mengajar dapat bertahan.
5. Keharmonisan

Pada berjalannya agenda bimbingan belajar nonformal di kampung Gemblakan Bawah, kerjasama yang dilakukan antar relawan pengajar berkomunikasi secara insentif untuk menghasilkan berbagai desain program. Menurut Badaruddin (2005:81-92) keharmonisan yang tercipta di sebuah komunitas sosial karena adanya hubungan antar individu yang secara sadar tidak ingin memicu permasalahan yang berujung pada konflik.

Perbedaan pendapat seringkali terjadi dalam forum pengambilan keputusan. Setiap relawan ingin menyuarakan pendapatnya serta merealisasikan sesuai opininya masingmasing. Antar relawan pengajar kampung Gemblakan Bawah komunitas Yogyakarta Mengajar tetap mengedapankan kedewasaan dalam berpendapat. Semua diselesaikan dengan kesepakatan forum. Tidak memiliki dendam karena pendapatnya tidak diterima. Hasil akhir adalah keputusan yang telah disepakati bersama serta plihan terbaik untuk keberlangsungan kegiatan komuitas Yogyakara Mengajar. Seperti yang dikatakan Badaruddin (2005:81-92) sebuah komunitas wajib mematuhi nilai-nilai sosial yang berlaku pada masyarakat. 
Kampung Gemblakan Bawah memiliki aturan-aturan yang berlaku pada masyarakat. Perilaku yang tidak sesuai dengan nilai yang ada dimasyarakat maka mengakibatkan kerusuhan yang berujung pada konflik.

Relawan pengajar di kampung Gemblakan Bawah secara konsisten menaati nilai-nilai serta aturan yang berlaku di masyarakat kampung Gemblakan Bawah. Relawan selalu berkomunikasi dengan tokoh masyarakat secara konsisten agar kesalahpahaman yang terjadi antara kedua belah pihak mampu terminimalisir.

\section{SIMPULAN}

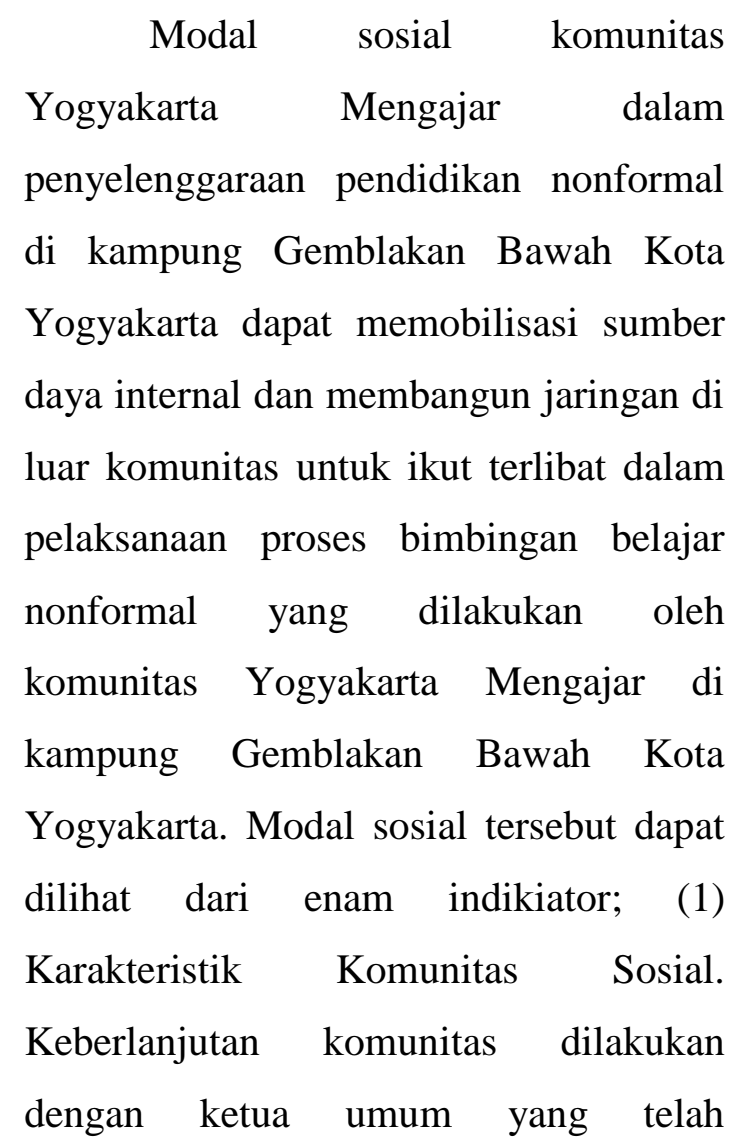

dikaderisasi saat menjadi relawan, pemilihannya secara langsung oleh relawan dan pengurus komunitas. Pembagian kerja komunitas dilakukan secara jelas. (2) Jaringan dan dukungan. Masyarakat kampung Gemblakan Bawah menyediakan tempat dan memberikan dana. Kegiatan komunitas Yogyakarta Mengajar di kampung Gemblakan Bawah berkolaborasi dengan organisasi lain. (3) Tindakan kolektif. Pertemuan rutin relawan. Pertemuan juga dilakukan dengan para ketua RW kampung Gemblakan Bawah untuk ikut terlibat dalam memberikan saran dan masukan. Laporan perkembangan peserta didik oleh relawan kepada orangtua peserta didik setiap bulannya satu kali. (4) Kepercayaan. Pembagian kerja antar relawan kampung Gemblakan Bawah tidak melihat latarbelakang pendidikan seorang relawan, satu sama lain memahami setiap relawan memiliki kapasitas yang sama dalam bekerja. Masyarakat kampung Gemblakan Bawah memiiki kepercayaan dengan relawan karena hasil yang telah diberikan berupa prestasi yang diraih oleh anak. (5) Solidaritas. Relawan pengajar tidak mendapatkan bayaran secara materi dalam melakukan bimbingan belajar di kampung Gemblakan Bawah. Relawan psecara rutin melakukan iuran untuk 
menunjang kegiatan komunitas Yogyakarta Mengajar serta ikut terlibat dalam kegiatan dana usaha komunitas Yogyakarta Mengajar. Tidak ada yang mendominasi peran antara pengurus dan relawan. Keduanya memiliki tugas utama sebagai seorang pengajar di kampung Gemblakan Bawah. (6) Relawan pengajar secara konsisten menaati nilai-nilai serta auran yang berlaku di kampung Gemblakan Bawah sehingga tidak pernah ada konflik yang terjadi. Konflik internal sekedar konflik kecil berupa perbedaan pendapat yang dapat diselesaikan dengan baik karena adanya kedewasaan sikap yang dimiliki oleh relawan komunitas Yogyakarta Mengajar.

\section{DAFTAR PUSTAKA}

Ahmadi, Abu. 2001. Ilmu Pendidikan. Jakarta: PT Rineka Cipta

Alfitri. 2011. Community Development Teori dan Aplikasi. Yogyakarta: Pustaka Pelajar

Arikunto,Suharsimi. 2002. Prosedur Penelitian Suatu Pendekatan Karakter. Jakarta: Rineka Cipta

Badaruddin. 2005. Modal Sosial (Social Capital) dan Pemberdayaan Komunitas Nelayan, Yogyakarta: Pustaka Pelajar

Cohen and Uphoff. 2002. Rural Development Participation concepts and measures for project design, implementation and evaluation. Cornel University. New York.
Dinas Pendidikan Pemuda dan Keolahragaan DIY, Laporan Kinerja Instansi Pemerintah Tahun 2016 Pemerintah Daearah Yogyakarta, Yogyakarta. http://www.pendidikandiy.go.id/img Igall/Laporan_Kinerja_Instansi_Pe merintah_Dinas_Dikpora_Tahun_2 016.pdf (Diunduh pada 02 Januari 2018)

Field, John. 2010. Modal Sosial. Medan: Media Perintis

Fukuyama, Francis. 2005. Guncangan Besar: Kodrat Manusia Dan Tata Sosial Baru. Jakarta: Gramedia Pustaka Utama.

Hariwijaya. 2007. Metodologi dan Teknik Penulisan Skripsi, Tesis dan Disertasi Untuk Ilmu-ilmu Sosial dan Humaniora. Yogyakarta: elmatera-publishing

Hasbullah, Jousairi. 2006. Social Capital (Menuju Keunggulan Budaya Manusia Indonesia). Jakarta: MR. United Press.

Joesoef, Soelaiman. 2004. Konsep Dasar Pendidikan Luar Sekolah. Jakarta: PT. Bumi Aksara

Kementerian Pendidikan dan Kebudayaan RI, Ikhtisar Data Pendidikan Tahun 2015-2017. publikasi.data.kemdikbud.go.id/upl oadDir/isi_FC1DCA36-A9D84688-8E5F-OFB5ED1DE869_.pdf (Diunduh pada 02 Januari 2018)

Moleong, Lexy J. 2006. Metodelogi Penelitian Kualitatif. Bandung: Remaja Rosdakarya

Mukti Wibowo, Yogo. 2012. Modal Sosial Pada Komunitas Motor di Yogyakarta (Studi pada Jogja Automotive Community 
Yogyakarta). Yogyakarta:

Universitas Negeri Yogyakarta

Nasution. 2003. Metode Penelitian Naturalistik Kualitatif. Bandung: Tarsito

Soekanto, Soerjono. 2006. Sosiologi Suatu Pengantar. Jakarta: Raja Grafindo

Sugiono. 2012. Memahami Penelitian Kualitatif. Bandung: Penerbit Alfabeta

Suryadi, Ace. 2016. Pendidikan Indonesia Menuju 2025: Permasalahan, Tantangan \& Alternatif Kebijakan. Bandung : PT Remaja Rosdakarya

Taneko,Soleman 1984. Struktur dan Proses Sosial Suatu Pengantar Sosiologi Pembangunan. Jakarta : CV. Rajawali

Yuanjaya, Pandhu. 2015. Modal Sosial dalam Gerakan Lingkungan : Studi Kasus di Kampung Gambiran dan Gondolayu Lor, Kota Yogyakarta. Natapraja Jurnal Kajian Ilmu Administrasi Negara, Volume 3 Nomor 1 Tahun 2015, hal 57-72 